\title{
CHALLENGES OF PROFESSIONAL POLICING FOR A SAFER TOURISM
}

\begin{abstract}
Janez Mekinc ${ }^{*}$ Katarina Mušič ${ }^{* *} \&$ Helena Cvikl ${ }^{* * *}$
Criminality is a key risk for tourism industry of any country or tourist destination. Tourist perception of safety is important decision making factor, no matter if decision is making for destination, accommodation or transport. The purpose of the research is to identify and analyse the forms of criminality in accommodation and catering. Main research aim is to analyse the forms and characteristics of criminal offences in Slovenian accommodation and hospitality facilities for the period 2007-2013. We performed a quantitative empirical research where the data on criminal offences in Slovenian hospitality was analysed and compared with the period 2007-2013. The research was based on the (crime record) databases of the Slovenian Police. The results are applied to practical solutions in the area of preventing criminal offences in accommodation and catering facilities, increase the safety of guests and co-operation between employees and hotel/motel management on one hand, and the police and security services on the other. The findings on the patterns of criminal offences in accommodation and catering facilities have a direct practical value for the tourism industry, especially for the management of hotels/motels.
\end{abstract}

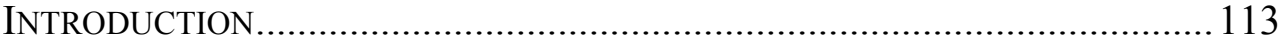

I. METHODOLOGICAL FrAMEWORK .................................................. 118

II. ANALYSIS .................................................................................. 120

A. Offences in Relation to the Days of the Week.......................... 122

B. Offences in Relation to the Months of the Year ........................ 123

C. Offences in Relation to the Location of the Hospitality

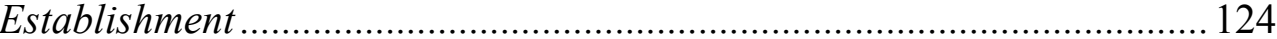

D. Nationality of Criminal Suspects ........................................ 126

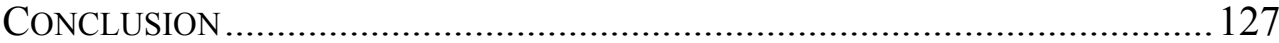

\footnotetext{
* Janez Mekinc, Ph.D., associate professor, Faculty of Tourism Studies Portorož, University of Primorska, Slovenia. Research field: crisis management in tourism, security and safety in tourism. Member of International Association of Chiefs of Police.

** Katarina Mušič is teaching assistant at the Faculty of Tourism Studies-Turistica, at the University of Primorska, Slovenia. Research field: safety and security in tourism, tourism management, exploitation of children and women in tourism.

${ }^{* * *}$ Helena Cvikl, M.Sc., Director of the Vocational College for Catering and Tourism Maribor and a lecturer for management in tourism, Faculty of Tourism Studies-Turistica, University of Primorska. Research field: quality in tourism and hospitality, security and safety in tourism.
} 


\section{INTRODUCTION}

Safety as a value can be found on the top of the hierarchical system of human values. Reactions of the individual, when his/her life or health is threatened, can be very hectic and uncompromising. Maslow's pyramid is very often the starting point for the treatment of different aspects of dealing with people. It is also clear that, security (protection from danger, illness, a predictable and organised environment, a permanent residence, lack of war, ...) has a special and important position in the hierarchy, considering the order of fulfilling the needs, namely immediately after fulfilling the basic physiological needs (Kranjc, 1982: 27) ${ }^{1}$. Olsen and Pizam ${ }^{2}$ (1999) established that, the threats and danger derive from three different levels; namely at the micro, mezzo and macro level. The micro level means hotel security; the mezzo level is tourist destination security; whereas the macro level is the national security and it is government responsibility. Tourism is the fastest-growing industry in recent decades, both in commercial as well as economic terms. The populations of developed countries have greater purchasing power and thus travel has become more affordable to different social classes and no longer considered a luxury commodity. As the economic situation allows, and the majority of the population can afford to travel, a fundamental factor in the choice of destination is its safety. In the past, there was a widely circulated positive message, originating from the tourism industry, advisors and some academics, that described "Tourism as a force of peace in the world", and which was used to make tourism even more popular. The fact is that, tourism has a very marginal influence on peace and safety phenomena; tourism depends much more on safety and security than vice versa (Hall, Timothy \& Duval, 2003) ${ }^{3}$. The global security environment will be practically impossible to predict in the future. Therefore the impact of security on the tourism development at individual destinations will be considerable. According to Miklavčič ${ }^{4}$ (2006: 16): "Global safety will be threatened by different sources of asymmetric threats, such as the appearance of 'new' terrorism, organised criminal offences,

\footnotetext{
${ }^{1}$ KrajnC A., MotivacijaZAizobražEVAnje (Motivation For EduCATION) 27 (Ljubljana: Delavskaenotnost 1982).

${ }^{2}$ Olsen M. D., \& Pizam A., Executive Summary: A White Paper from the IH \& RA Think Tank on Safety and Security, (Paris: International Hotel and Restaurant Association 1999).

${ }^{3}$ Hall C. M., Timothy D. J., \& Duval D. T., Security and Tourism: Towards a New Understanding, SAFETY AND SECURITY In TOURISM-Relationships, MANAGEMENT AND MARKETING 1-18 (C. M. Hall, D. J. Timothy, \& D. T. Duval eds., Binghamton: The Haworth Hospitality Press 2003).

${ }^{4}$ Miklavčič M., (2006). Globalnavarnost in Turizem v Sloveniji (Global Safety and Tourismin Slovenia), Globalnavarnost v TuRizMu v SloveniJi: Zbornikreferatov: ProceEdings 12-8 (M. Faletič, \& B. Djutović eds., Ljubljana: Državnisvet Republike Slovenije 2006).
} 
uncontrolled migration currents, trafficking with people, pollution of the environment, local military conflicts, political changes in individual countries, natural disasters and catastrophes, deriving from climate changes". The influence of threats to the tourism destination can vary, but criminal offences occur everywhere.

Tourist industry is becoming one of the most important a globally economic activity and tourism efficiency is based on security. The last few years, the global fight against terrorism has raised security onto a pedestal, removing human rights and liberties, the right to just trials and last but not least, human dignity (Mekinc, 2007: 13) ${ }^{5}$. Global security risks are a combination of political, social, ecological and psychological factors (Ambrož \& Mavrič, 2004: 199) ${ }^{6}$. Relationship between security and human rights can be transferred and combined with the relationship between safety on one hand, and freedom, genuine pleasure, discreteness and integrity on the other. Both relationships are reciprocal in their quantity and quality. For tourism, we can define: more security measures-less freedom and genuine pleasure is present in tourism activities (Mekinc, 2010: 28) ${ }^{7}$.

Europe is the world's number one tourism destination. In 2013, more than 560 million international tourists arrived in Europe; the figure surpassed the very high numbers in 2012, with particularly strong tourist growth in South and Central Europe, according to the UNWTO ${ }^{8}$. Europe is also the preferred tourist destination for Europeans themselves. In 2013, almost $40 \%$ of Europeans stayed in the EU, 5\% more than in 2012. According to the latest Eurobarometer ${ }^{9}$ analysis, tourists in Europe felt safe and very satisfied. Survey respondents expressed a high degree of satisfaction in terms of their holidays in 2013, especially security $(95 \%)$ and the quality of their accommodation (95\%). It can be seen that, the destinations with large numbers of tourists also have higher crime rates. This indicates a link between tourism growth and crime rates, although it is not the only reason. Tourism crime is usually widely known and warned about in those areas it is related to, and it is easy to blame tourism for many

\footnotetext{
${ }^{5}$ Mekinc J., Model Etičnihstališčnaravnehstrateškega in Operativnegamanagementa v Slovenskipoliciji (Model of the Ethical Standpoint on the Level of Strategic and Operative Police Managers in the Slovene Police), DOCTORAL DiSSERTATION 13 (Kranj: Univerza v Mariboru, Fakultetazaorganizacijskevede 2007).

${ }^{6}$ Ambrož M., \& Mavrič M., Varnostkotmotivzaturističnopotovanja (Safety and Security as a Motive for Tourist Travel), 6(3) VARSTVOSLOVJE 197-206 (2004).

${ }^{7}$ Mekinc J., Varnost je Tudi v Krizivrednotaturističnegaprodukta in Ponudbe (Safety is an value of tourist Product and Offer Also within Acrisis), 55(3) DELO + VARNOST 27-35 (2010).

${ }^{8}$ World Tourism Organisation UNWTO Tourism Barometer, (January 2014).

${ }^{9}$ European Commission-IP/14/144, 13/02/2014 Pressrelease, Tourism Expected to Grow Again in 2014, Led by Strong Domestic and European Demand, (February 2014).
} 
problems. Areas with growing tourism usually also have a rising population rate, which can affect the increase in the crime rate (Goeldner \& Ritchie, $2009^{10}$; Weaver \& Oppermann, 2000 ${ }^{11}$ ).

Tourism is a key economic sector, which contributes to the image of a country. Safety and all its elements become a key factor in the quality and development of tourism and needs to be considered seriously at all levels of the tourist offer (safety of tourists and tourist destinations). According to Mansfeld \& Pizam ${ }^{12}$ (2006), people may cancel their bookings, avoid booking trips to affected destinations or, for those who are already in an affected destination, move to a safer place or return home. There is also a change in the risk-taking tendency of various tourist segments. Some people use risk-related travel information prior to choosing their choice of destination. Regrettably, tourism is also linked to specific forms of crime fuelled by the mobility and the vulnerability of tourists who may be disoriented, in an unfamiliar environment, particularly due to ignorance of the local culture and often not able to speak the language. Tourists are tempting targets, due to their wealthier lifestyles, which some locals hope to get for themselves (Tarlow, 2006) ${ }^{13}$. Indeed, the economic success or failure of a tourism destination depends in part on its ability to ensure the safety of its visitors. Tourism brings different kinds of people together, people from different economic situations and cultures.

Governments and Local Authorities attempt to develop measures and methods in order to prevent and fight crime targeted towards tourists, but also the nuisance caused by tourism and specific forms of crimes linked to tourism. The main objective is to guarantee the best possible coexistence between tourists and the local population. Tourism security issues should be addressed through local partnerships and by introducing necessary publicprivate partnerships. It is a fact that, tourists are wholly citizens of the cities they visit, even if only temporarily. Safety, therefore, is not just something alongside tourism, but rather it is a component, because one cannot expect modern tourism to develop in an area that is not safe (Rožič, 2006) ${ }^{14}$.

\footnotetext{
${ }^{10}$ Goeldner Charles R., \& Richie J. R. Brent, Tourism—Principles, Practices, Philosophies (New Jersey: John Wiley \& Sons, Inc. 2009).

${ }^{11}$ Weaver D., \& OpPermann M., Tourism MANagement (Singapore: John Wiley \& Sons Australia, Ltd. 2000).

${ }^{12}$ Mansfeld Y., \& Pizam A., Tourism, Security and Safety: From Theory to Practice (Burlington: Elsevier Butterworth-Heinemann 2006).

${ }^{13}$ Tarlow Peter E., Crime and Tourism, Tourism in Turbulent Times-TOwards SAfe EXPERIEnCE FOR VISITORS (Wilks, Pendergast, \& Leggat eds., United Kingdom: ELSEVIER Ltd. 2006).

${ }^{14}$ Rožič M., O Varnosti v Turizmu (About Safety within Tourism), GLOBALNAVARNOST v TURIZMU V SLOVEniJ: Zbornikreferatov: ProceEdings 10 (M. Faletič, \& B. Djutović eds., Ljubljana: Državnisvet Republike Slovenije 2006).
} 
The findings of this analysis show that, the impact of security incidents on the tourism industry, tourist destinations, the local community and for tourists is, in all cases, negative and far-reaching (Mansfeld, 2006); of these, crime is the most common security incident. The crime rate and the effectiveness of the security forces to combat it is one of the key factors for a country with a tourism industry. Tourists are reluctant to travel to countries that are not safe and are therefore much less attractive for the development of the tourism sector. Hreščak (2010) states that, safety is now becoming one of the key criteria by which tourists decide whether to visit a particular country or not. The World Economic Forum (WEF), in a 2013 report on competitiveness in the tourism sector of 141 states, placed special emphasis on security as an important pillar in a competitive tourism industry. Security is assessed according to the degree of crime, the threat of terrorism, the effectiveness of the security authorities and road safety. The report highlights Switzerland, Germany and Austria as the most competitive European countries in the field of tourism, with Slovenia occupying 36th place out 141 countries; while in the security pillar Slovenia occupies 26th place (World Economic Forum, 2013) ${ }^{15}$.

On the security index, measured by the Institute for Economics and Peace, in 2013, Slovenia was ranked 13th among 159 countries, which is five places lower than in 2012 when we were ranked 8th, and in 10th place in 2011 (Global Peace Index 2013) $^{16}$. The results still rank Slovenia among the countries considered to have above average parameters according to Mekinc and Dobovšek (2011) ${ }^{17}$. This means that, tourists perceive Slovenia as a safe country in line with Europe's safest destinations.

Security has becoming a key factor in decision making related travel and tourism. Tourist safety perception in European destinations is relatively high. However, Euro barometer research ${ }^{18}$ (2009) defined safety and security as a most important decision-making factor in Denmark, Cyprus and Malta. Safety is also very important for Slovenes (18\%), only exceeded by price $(24 \%)$ and quality $(22.2 \%)$. Furthermore, the results defined safety

\footnotetext{
${ }^{15}$ World Economic Forum, The Travel \& Tourism Competitiveness Report 2013. Available at http://www3.weforum.org/docs/WEF_TT_Competitiveness_Report_2013.pdf (last visited May 8, 2014).

${ }^{16}$ Global Peace Index 2013. Available at

http://www.theguardian.com/news/datablog/2013/jun/11/global-peace-index-2013 (last visited July 8, 2014).

${ }^{17}$ Mekinc J., Dobovšek B., Uvodnik V. J. Mekinc, \& B. DobovšEk, VARnost v Turizmu (Str.7) (B. Dobovšek ed., Koper: Univerzana Primorskem, Znanstveno-Raziskovalnosredišče, Univerzitetnazaložba Annales 2011).

${ }^{18}$ Eurobarometer-Press Releases Database (February 2014). Available at http://europa.eu/rapid/press-release_IP-14-144_en.htm (last visited May 8, 2014).
} 
and security as especially important factor for women (15.4\%), whereas it is less important for men (only 10.9\%) (The Gallup Organisation, 2009) ${ }^{19}$.

A free market offers many opportunities for tourism industry managers to make profits. However, this practice also gives opportunities for criminal activities. Freedom of movement, capital, people and services are very often misused by criminals (Edelbacher, Theil, \& Kratcoski, 2012) ${ }^{20}$. Crime certainly represents one of the most serious threats to modern tourism. Property crime significantly increases during the tourist season and the number of crimes in the tourist parts of the city increases; McPeters and Stronge already found this out in 1974, in their study linking crime and tourism in Miami (in Brunt, Mawby and Hambly, 2000) ${ }^{21}$. Crime as a threat to tourism can occur in a variety of forms (larceny, theft, robbery, rape, murder, piracy, kidnapping, etc.). It can be a normal, spontaneous crime by local residents towards tourists, tourists towards locals or tourists towards tourists (Kurez, 2013) 2 $^{22}$. For many, tourist destinations offer the potential for unacceptable behaviour and the opportunity to victimise people. These are "due to being relaxed, feeling free and being inattentive to safety / ... / giving in, offering, taking part in and being part of situations that are uncharacteristically enjoyable. In doing so, however, people tend to forget their physical, material and mental wellbeing" (Pečar, 1999) ${ }^{23}$. It can be said that, both tourism, as well as crime, are deviant behaviours. The only difference is that, crime is not socially acceptable, while tourism is (Ryan and Kinder in Brunt, et al., 2000) $)^{22}$.

Combating tourism crime requires the development of targeted procedures designed, according to the morphological characteristics of tourism crime and types of tourism crime. Controlling the time aspects requires that, government departments determine the relevant legal measures for crime prevention according the highs and lows of tourism crime, which occur during the peak season and the off season. Furthermore, controlling the space aspects requires government departments to transfer their primary concern for the prevention of tourism crime from people to

\footnotetext{
${ }^{19}$ Gallup Organisation, Flash Eurobarometer 258-Survey on the Attitudes of Europeans towards Tourism, Acquired, (2009). Available at $\mathrm{http} / / /$ ec.europa.eu/public_opinion/flash/fl_258_en.pdf (last visited April 20, 2010).

${ }^{20}$ Edelbacher M., \& Norden G., Development toward a Security Society, FinANCIAL CRIMES: A Threat to Global Security 37-50 (M. Edelbacher, P. Kratcoski, \& M. Theil eds., Boca Raton: CRC Press 2012).

${ }^{21}$ Brunt P., Mawby R., \& Hambly Z., Tourist Victimization and the Fear of Crime on Holiday, 21 TOURISM MANAGEMENT 417-24 (2000).

${ }^{22}$ Kurež B., Sodobnovarnostnookolje in Turizem, 13(3) VARSTVOSLOvjE 330-47 (2013).

${ }^{23}$ Pečar J., Viktimološkipogledi na Turizem-Turističnakriminaliteta, VARNOST IN TURIZEM 315-28. (V. A. Anžič ed., Ljubljana: Visokapolicijsko-Varnostnašola 1999).
} 
places. In addition, controlling the victim aspects of the tourist destination, requires tourist and government stakeholders to work together to prevent crime. Tourists should take the initiative to minimise those factors which include the tourists' own appeal and the motives of the potential offenders $\left(\right.$ Wai, 2013) ${ }^{24}$.

Safety perception is very important decision making fact. Different occurrences of safety and security incidents cause a change in the perception of tourists toward the risk they are prepared to take when travelling (Mansfeld \& Pizam, 2006: 7) ${ }^{25}$. In the past, there was a widely circulated positive message, sent from the tourism industry, advisors and some academics, saying "Tourism as a force of peace in the world", used for the purpose of turning tourism even more popular. The fact is that, tourism has a very marginal influence on peace and safety phenomena; tourism depends much more on safety and security than vice versa (Hall, Timothy \& Duval, 2003: 3$)^{26}$.

\section{MethodologicAL FrameWORK}

An analysis of the literature shows several studies that deal specifically with the issue of safety and security at certain destinations ${ }^{27}$ (Nadir \& Hussain, 2005 28 ; Juwaheer \& Roos, 2005 ${ }^{29}$; Camilleri, 2006 ${ }^{30}$; Ajagunna, $2006^{31}$; Eraqi, 2006 ${ }^{32}$ ). Even though some give us very detailed views of the actual situation, we cannot directly compare data because of the particular economy, culture, society, geographical position, etc.. These findings are,

\footnotetext{
${ }^{24}$ Wei Y., Crime Field Analysis and the Control of Tourism Crime, 28(10) TOURISM TrIBUNE 107-13 (2013).

${ }^{25}$ Mansfeld Y., \& Pizam A., Tourism, Security and Safety: From Theory to Practice (Burlington: Elsevier Butterworth-Heinemann 2006).

${ }^{26}$ Hall C. M., Timothy D. J., \& Duval D. T., Security and Tourism: Towards a New Understanding,

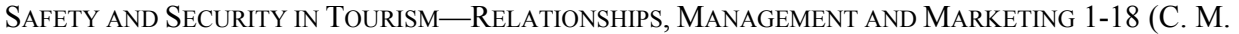
Hall, D. J. Timothy, \& D. T. Duval eds., Binghamton: The Haworth Hospitality Press 2003).

${ }^{27}$ Cyprus, Mauritius, Mediterranean, Jamaica and Egypt.

${ }^{28}$ Nadiri H., \& Hussain K., Perceptions of Service Quality in North Cyprus Hotels, 17(6) INTERNATIONAL JOURNAL OF CONTEMPORARY HOSPITALITY MANAGEMENT 469 (2005).

${ }^{29}$ Juwaheer T. D., \& Roos D. L., A Study of Hotel Guest Perceptions in Mauritius, 15(2) INTERNATIONAL JOURNAL OF CONTEMPORARY HOSPITALITY MANAGEMENT 105-15 (2005).

${ }^{30}$ Camilleri D. H., Tsunami Construction Risks in the Mediterranean-Outlining Malta's Scenario, 15(1) Disaster Prevention And MANagement 146-62 (2006).

${ }^{31}$ Ajagunna I., Criminal Offence and Harassment in Jamaica: Consequences for the Sustainability of the Tourism Industry, 18(3) INTERNATIONAL JOURNAL OF CONTEMPORARY HOSPITALITY MANAGEMENT 253-9 (2006).

${ }^{32}$ Eraqi M. I., Egypt, Tourism Services Quality (TourServQual) in Egypt, the Viewpoints of External and Internal Customers, 13(4) BENCHMARKING: AN INTERNATIONAL JOURNAL BIJ, SPECIAL ISSUE ON TQM (2006).
} 
however, an important source of information for discussing the analysis of the crimes in accommodation and hospitality facilities in Slovenia ${ }^{33}$ presented in this paper.

For this research, we used tourism crime offence data for the period 2007-2013 in the analysis of crimes related to tourism; the data was obtained from the web pages of the Slovenian Police (Under the Statistics subpage - Criminal-Data in .txt format ${ }^{34}$; and from the Police directly (Ministry of Interior). The data obtained from the webpage (in txt format) was imported into SPSS, and then tabulated for the period 2007-2013. A database combining all criminal offences (co) over the period of 2007-2013 was obtained. We also used and compared the data for tourist arrivals and overnight stays from the SI-STAT ${ }^{35}$ data portal. This large database helped us to analyse which of the criminal offences, taking place in accommodation and hospitality facilities have the characteristics of tourism-related offences.

Based on the analysis of the data for the period 2007-2013, the results were prepared for comparison:

- between the frequency of specific crimes in accommodation and hospitality facilities ${ }^{36}$;

- between the number of offences in relation to the days of the week and months of the year;

- between the number of tourists and the number of offences detected during the period;

- of the number and types of crime, by the location of the accommodation and hospitality facilities during the period;

- between the number of tourist arrivals and the number of reported offences;

- between the number of crimes in the accommodation and hospitality facilities by nationality of suspects and victims (individuals).

Unfortunately, the data analysed does not provide information on how the crimes were committed, who the offenders were, and the amount of damage caused.

\footnotetext{
${ }^{33}$ The Statute on the minimum technical requirements and the minimal volume of services for the purpose of providing activities (OFFICIAL JOURNAL OF THE RS, No. 88/2000) lists the following types under accomodation and hospitality facilities: hotels, motels, bed \& breakfasts, lodgings, hotels and apartment villas, mountain and other lodges, camps, accommodation, inns, coffeehouses, patisseries, eateries, bars and catering facilities.

${ }^{34}$ Criminality—Statistics. Available at $\mathrm{http}$ ://www.policija.si/index.php/statistika/kriminaliteta.

${ }^{35}$ Statistical Office of the Republic of Slovenia.

${ }^{36}$ Regulations on the Minimal Conditions and Scope for Provision of Hospitality Services.
} 


\section{ANALYSIS}

The data analysed related to 117 different offences. Due to the large number of different offences, we decided to graphically represent the distribution of the 10 most frequently repeated offences detected in the period 2007-2013.

Table 1 The most frequent (top 10) offences in the period 2007-2013.

\begin{tabular}{llllllll}
\hline \multirow{2}{*}{$\begin{array}{l}\text { Offence according to the definition } \\
\text { in the Criminal Code }\end{array}$} & \multicolumn{7}{c}{ YEAR } \\
\cline { 2 - 8 } & 2007 & 2008 & 2009 & 2010 & 2011 & 2012 & 2013 \\
\cline { 2 - 8 } Larceny & 1,885 & 1,779 & 1,794 & 1,588 & 1,711 & 2,067 & 1,945 \\
Burglary & 1,606 & 1,377 & 1,916 & 1,550 & 1,590 & 1,511 & 1,768 \\
Actual bodily harm & 483 & 378 & 364 & 363 & 345 & 335 & 297 \\
Counterfeit money & 290 & 274 & 346 & 262 & 193 & 198 & 284 \\
Damage to property & 316 & 261 & 275 & 246 & 218 & 248 & 231 \\
Fraud & 141 & 189 & 254 & 237 & 200 & 223 & 193 \\
Threat & 247 & 208 & 212 & 204 & 217 & 96 & 30 \\
Misappropriation & 166 & 154 & 140 & 135 & 156 & 160 & 169 \\
Violent conduct & 93 & 88 & 75 & 80 & 86 & 70 & 56 \\
*Production and trade in illicit drugs & 43 & 39 & 31 & 114 & 36 & 57 & 59 \\
Total & 5,270 & 4,747 & 5,407 & 4,779 & 4,752 & 4,965 & 5,023 \\
\hline
\end{tabular}

(Source: Annual Police Reports 2007-2013; author).

"The illegal manufacture of, and trafficking in, narcotic drugs, doping substances in sport, and constituents for illicit drug production.

The findings suggest that, larceny and burglary are the most prevalent criminal offences (Table 1). The number of offences over all the seven years analysed, are as follows: actual bodily harm, counterfeit money, damage to property, fraud, threats, misappropriation, violent conduct and the illegal manufacture of, and trafficking in, narcotic drugs, doping substances in sport, and constituents for illicit drug production. Counterfeiting money is particularly common in casinos, and other locations where theft prevails. This shows that, in most cases of typical crime, the offenders generally do not need any special skills or tools.

A comparison between tourists visiting Slovenia each year and the number of crimes occurring in accommodation and hospitality facilities, do not show any trend. One would expect that, with a larger number of tourists, there would also be an increased number of offences, but the results of the comparison (Table 2), do not confirm this. 
Table 2 Comparison between the number of tourists and the number of detected offences in 2007-2013.

\begin{tabular}{|c|c|c|}
\hline Year & Number of tourists & Number of offences ${ }^{*}$ \\
\hline & Total: $2,681,178$ & \\
\hline \multirow[t]{3}{*}{2007} & Foreign: $1,751,332$ & 5,917 \\
\hline & Domestic: 929,846 & \\
\hline & Total: 2,766,199 & \\
\hline \multirow[t]{3}{*}{2008} & Foreign: $1,771,237$ & 5,230 \\
\hline & Domestic: 994,957 & \\
\hline & Total: 2,722,002 & \\
\hline \multirow[t]{3}{*}{2009} & Foreign: $1,668,098$ & 5,904 \\
\hline & Domestic: $1,053,904$ & \\
\hline & Total: $3,006,272$ & \\
\hline \multirow[t]{3}{*}{2010} & Foreign: $1,869,106$ & 5,251 \\
\hline & Domestic: $1,137,166$ & \\
\hline & Total: $3,217,966$ & \\
\hline \multirow[t]{3}{*}{2011} & Foreign: $2,036,652$ & 5,190 \\
\hline & Domestic: $1,181,314$ & \\
\hline & Total: $3,297,556$ & \\
\hline \multirow[t]{3}{*}{2012} & Foreign: $2,155,612$ & 5,479 \\
\hline & Domestic:1,141,944 & \\
\hline & Total: $3,384,491$ & \\
\hline \multirow[t]{2}{*}{2013} & Foreign:2,258,570 & 5,604 \\
\hline & Domestic: $1,125,921$ & \\
\hline
\end{tabular}

(Source: Annual Police Reports 2007-2013, SI-STAT; author).

* Covers all crimes committed in accommodation and hospitality facilities in a given year.

Table 2 shows that, in 2007, the least number $(2,681,178)$ of foreign and domestic tourists recorded the most offences $(5,917)$. The maximum numbers of tourist arrivals were recorded in $2013(3,384,491)$ with the police recording 5,604 crimes in accommodation and hospitality facilities. In comparing the results of the two variables, we found that, the number of tourists constantly increases every year, while the number of crimes committed in accommodation and hospitality facilities varies from year to year. An increased number of tourists does not affect the number of crimes, even though the number of tourists between $2007(2,681,178)$ and 2013 $(3,384,491)$ increased by $26.2 \%(703,313)$. The number of crimes in a given period is affected by numerous other factors, such as the effectiveness of the police and judicial system, the general socio-economic situation, the security situation, investments in security infrastructure etc.. 


\section{A. Offences in Relation to the Days of the Week}

For security authorities and managers of accommodation and hospitality facilities, one interesting fact must be which day of the week do most crimes occur and, of course, where they take place. The results for 2007-2013 (Table 3) show that, most offences take place at the weekend, so on Friday, Saturday and Sunday, when visits by tourists and others are higher, rather than during working weekdays. During these three days, Saturday stands out with $4.2 \%$ more crimes committed than the average for the whole week.

Table 3 Number of offences in relation to the day of the week.

\begin{tabular}{llllllllll}
\hline $\begin{array}{l}\text { NUMBER OF } \\
\text { OFFENCES }\end{array}$ & \multicolumn{10}{c}{ Year } \\
\hline Day of the week & 2007 & 2008 & 2009 & 2010 & 2011 & 2012 & 2013 & Total & $\%$ \\
Monday & 712 & 654 & 792 & 654 & 661 & 715 & 767 & 4,955 & 12.8 \\
Tuesday & 703 & 555 & 718 & 623 & 628 & 608 & 657 & 4,492 & 11.6 \\
Wednesday & 723 & 642 & 773 & 698 & 671 & 667 & 746 & 4,920 & 12.7 \\
Thursday & 726 & 655 & 718 & 683 & 641 & 672 & 707 & 4,802 & 12.5 \\
Friday & 890 & 741 & 860 & 770 & 778 & 922 & 856 & 5,817 & 15.1 \\
Saturday & 1,154 & 1,028 & 1,019 & 927 & 982 & 1,006 & 1,015 & 7,131 & 18.5 \\
Sunday & 1,009 & 955 & 1.024 & 896 & 829 & 889 & 856 & 6,458 & 16.8 \\
Total & 5,917 & 5,230 & 5,904 & 5,251 & 5,190 & 5,479 & 5,604 & 38,575 & 100 \\
$\bar{x}$ & & & & & & & & 5,510 & 14.3 \\
\hline
\end{tabular}

(Source: Annual Police Reports 2007-2013; author).

Data analysis suggests the need for greater attention to crime prevention at the weekends. One should not overlook the fact that, due to the increased number of tourists and visitors at the weekends, the staff in accommodation and hospitality facilities have a greater workload and are therefore less focused on potential offenders. Similarly, due to the large number of events held over the weekend, the security authorities also have increased workload, providing offenders with easier opportunities to target premises, carry out offences and leave the crime scene. Owners and managers of accommodation and hospitality facilities should increase their weekend security or security guards in crime prevention measures that reduce the number of offences. Similarly, it is not only the direct damage caused by criminal acts, but also the reputation of the hospitality facility as a safe location, which is especially important for attracting visitors and tourists. Successful crime prevention and preventive measures require cooperation between the staff and management of the accommodation and hospitality facilities, the local community, police and private security services, who are jointly responsible for the security of these facilities. 


\section{B. Offences in Relation to the Months of the Year}

Tourism is an economic activity whose performance is affected by the seasons. In Slovenia, the seasons are separated into the summer season (July, August) and winter season (February, March). Tourist workers obviously try to prolong the season during the year, but according to SI-STAT ${ }^{37}$ data for the period from 2007 to 2013, the highest number of tourist arrivals and overnight stays in accommodation and hospitality facilities took place in the summer season, i.e., in the months of July and August. On the basis of this data, one would conclude that, most offences are recorded during the summer high season, so in July and August (Table 4); and here, more offences were recorded in July, $0.2 \%$ on average, and $0.4 \%$ on average more offences in August than in the other months of the year.

Table 4 Number of offences per month during the period 2007-2013.

\begin{tabular}{|c|c|c|c|c|c|c|c|c|c|c|c|c|c|c|c|c|}
\hline \multirow{2}{*}{$\begin{array}{l}\text { Number of } \\
\text { offences/ } \\
\text { month }\end{array}$} & \multicolumn{2}{|l|}{2007} & \multicolumn{2}{|l|}{2008} & \multicolumn{2}{|l|}{2009} & \multicolumn{2}{|l|}{2010} & \multicolumn{2}{|l|}{2011} & \multicolumn{2}{|l|}{2012} & \multicolumn{2}{|l|}{2013} & \multirow{2}{*}{$\begin{array}{l}\text { Total } \\
\text { No. Off. }\end{array}$} & \multirow{2}{*}{$\frac{\text { Total }}{\%}$} \\
\hline & $\begin{array}{l}\text { No. } \\
\text { Off. }\end{array}$ & $\%$ & $\begin{array}{l}\text { No. } \\
\text { Off. }\end{array}$ & $\%$ & $\begin{array}{l}\text { No. } \\
\text { Off. }\end{array}$ & $\%$ & $\begin{array}{l}\text { No. } \\
\text { Off. }\end{array}$ & $\%$ & $\begin{array}{l}\text { No. } \\
\text { Off. }\end{array}$ & $\%$ & $\begin{array}{l}\text { No. } \\
\text { Off. }\end{array}$ & $\%$ & $\begin{array}{l}\text { No. } \\
\text { Off. }\end{array}$ & $\%$ & & \\
\hline January & 530 & 8.9 & 428 & 8.2 & 429 & 7.3 & 450 & 8.6 & 414 & 8.0 & 422 & 7.7 & 451 & 8.0 & 3,124 & 8.1 \\
\hline February & 512 & 8.7 & 420 & 8.0 & 466 & 7.9 & 488 & 9.3 & 420 & 8.1 & 491 & 9.0 & 349 & 6.2 & 3,146 & 8.2 \\
\hline March & 559 & 9.4 & 448 & 8.6 & 526 & 8.9 & 435 & 8.3 & 440 & 8.5 & 465 & 8.5 & 428 & 7.7 & 3,301 & 8.4 \\
\hline April & 496 & 8.5 & 411 & 7.8 & 487 & 8.2 & 386 & 7.3 & 424 & 8.2 & 447 & 8.2 & 512 & 9.2 & 3,163 & 8.2 \\
\hline May & 464 & 7.9 & 429 & 8.3 & 473 & 8.0 & 404 & 7.7 & 388 & 7.5 & 438 & 8.0 & 602 & 10.7 & 3,198 & 8.3 \\
\hline June & 476 & 8.0 & 389 & 7.4 & 465 & 7.9 & 388 & 7.4 & 440 & 8.5 & 419 & 7.6 & 527 & 9.4 & 3,104 & 8.0 \\
\hline July & 473 & 7.9 & 415 & 7.9 & 549 & 9.3 & 400 & 7.6 & 500 & 9.6 & 439 & 8.1 & 511 & 9.1 & 3,287 & 8.5 \\
\hline August & 445 & 7.5 & 526 & 10.1 & 550 & 9.4 & 439 & 8.5 & 431 & 8.3 & 478 & 8.7 & 473 & 8.4 & 3,342 & 8.7 \\
\hline September & 429 & 7.2 & 407 & 7.8 & 446 & 7.5 & 367 & 7.0 & 404 & 7.8 & 510 & 9.3 & 453 & 8.1 & 3,016 & 7.9 \\
\hline October & 480 & 8.1 & 431 & 8.2 & 518 & 8.8 & 467 & 8.8 & 448 & 8.6 & 416 & 7.5 & 405 & 7.3 & 3,165 & 8.2 \\
\hline November & 483 & 8.2 & 404 & 7.7 & 496 & 8.3 & 469 & 8.9 & 381 & 7.3 & 468 & 8.6 & 392 & 7.0 & 3,093 & 8.0 \\
\hline December & 570 & 9.7 & 522 & 10 & 499 & 8.4 & 558 & 10.6 & 500 & 9.6 & 486 & 8.8 & 501 & 8.9 & 3,636 & 9.5 \\
\hline Total & 5,917 & 100 & 5,230 & 100 & 5,904 & 100 & 5,251 & 100 & 5,190 & 100 & 5,479 & 100 & 5,604 & 100 & 38,575 & 100 \\
\hline$\overline{\mathrm{x}}$ & & & & & & & & & & & & & & & & 8.3 \\
\hline
\end{tabular}

(Source: Annual Police Reports 2007-2013; author).

The same conclusion does not apply to the winter season, which is especially true for the month of February, since it does not stand out from the other months, and has $0.1 \%$ fewer crimes than the average of the other months. On average, March has $0.1 \%$ more crimes. Particular attention should be given to December, as a comparative analysis of the seven years

\footnotetext{
${ }^{37}$ Statistical Office of the Republic of Slovenia, Accommodation Facilities, Tourist Arrivals and Overnight Stays by Types of Tourist Accommodations, (Slovenia Monthly). Available at http://pxweb.stat.si/pxweb/Dialog/varval.asp?ma=2164401S\&ti=\&path=../Database/Ekonomsko/21_g ostinstvo_turizem/01_21644_nastanitev_mesecno/\&lang=2.
} 
studied shows that, the numbers of crimes are accentuated in the winter month of December, which has an average of $1.2 \%$ more crimes than the average of the other months. The results of the research show that, on average, most crime happens in December, which is interesting as, according to SI-STAT ${ }^{38}$, there is no recorded increase in arrivals and overnight stays, as are recorded in July and August. In these months, Slovenia has by far the most arrivals and overnight stays by domestic and by foreign visitors. The fact is that, during the summer tourist season, the police carried out a series of crime prevention campaigns that raise awareness of how tourists can take care of their property, which certainly contributes to greater security.

\section{Offences in Relation to the Location of the Hospitality Establishment}

An important part of the study presents a comparative analysis of the number of offences at specific locations, such as individual accommodation and hospitality facilities. The distributions of individual facilities by categories, as set out in Table 5, were recorded in a database collected by the Police on determining an offence.

Table 5 Number of crimes by the location of the accommodation and hospitality facilities in 2007-2013.

\begin{tabular}{|c|c|c|c|c|c|c|c|c|c|}
\hline & & & & Year & & & & & \\
\hline $\begin{array}{l}\text { Detailed description of } \\
\text { location }\end{array}$ & 2007 & 2008 & 2009 & 2010 & 2011 & 2012 & 2013 & Total & $\%$ \\
\hline $\begin{array}{l}\text { Catering facilities } \\
\text { (restaurant, bar, snack bar, } \\
\text { pastry shop) }\end{array}$ & 4,431 & 3,898 & 4,603 & 4,096 & 3,862 & 3,792 & 3,872 & 28,554 & 74 \\
\hline $\begin{array}{l}\text { Holiday home (cottage), } \\
\text { bungalow, caravan }\end{array}$ & 842 & 682 & 692 & 543 & 724 & 902 & 1,050 & 5,435 & 14.1 \\
\hline $\begin{array}{l}\text { Hotel, motel (excl. manage- } \\
\text { ment, catering \& retail } \\
\text { space) }\end{array}$ & 302 & 297 & 290 & 237 & 323 & 494 & 416 & 2,359 & 6.1 \\
\hline Gaming/Casino & 258 & 277 & 238 & 296 & 188 & 149 & 148 & 1,554 & 4.1 \\
\hline Camping & 52 & 54 & 56 & 45 & 59 & 119 & 93 & 478 & 1.2 \\
\hline Vacation or Mountain hut & 32 & 22 & 25 & 34 & 34 & 23 & 25 & 195 & 0.5 \\
\hline Total & & & & & & & & 38,575 & 100 \\
\hline$\overline{\mathrm{x}}$ & & & & & & & & & 16.7 \\
\hline
\end{tabular}

(Source: Annual Police Reports 2007-2013; author).

Table 5 shows that, most crimes were committed in bars and restaurants, which is also the highest by category. On average, $57.3 \%$ more

\footnotetext{
${ }^{38}$ Statistical Office of the Republic of Slovenia, Accommodation Facilities, Tourist Arrivals and Overnight Stays by Types of Tourist Accommodations, (Slovenia Monthly).
} 
crimes occur in bars and restaurants than in other locations. The least crime takes place in camps and campsites, and in holiday or mountain huts. We reason that, the number of crimes affecting the small number of holiday or mountain huts is low compared to other locations, due to the kinds of guests and visitors going to or staying in lodges or holiday homes. The larger number of offences in the "Holiday home (cottage), bungalow, caravan," category is a reflection of the large number of privately owned cottages and apartments found in Slovenia, but these do not stand out from the average by the number of offences.

A comparative analysis between the number of offences, such as the 10 most common crimes and the locations where they were committed (Table 6), confirms the hypothesis that, the majority are larceny, burglary, actual bodily harm, counterfeit money and damage to property. We can conclude that, the frequencies of individual crimes are directly related to the activities that are carried out at the location. This is also confirmed by the fact that, for the period from 2007 to 2013, there were no reports of criminal offences such as business fraud, falsification of documents, arson and embezzlement and unauthorized use of another's property in campsites and holiday and mountain lodges.

Table 6 Number of the most common crimes (top 10) committed in different locations in the period 2007-2013.

\begin{tabular}{|c|c|c|c|c|c|c|c|}
\hline $\begin{array}{l}\text { The number of crimes in the } \\
\text { period } 2007-2013 \text { by location }\end{array}$ & $\begin{array}{l}\text { Catering } \\
\text { establishment }\end{array}$ & $\begin{array}{l}\text { Hotel, } \\
\text { t motel }\end{array}$ & $\begin{array}{l}\text { Gaming/ } \\
\text { Casino }\end{array}$ & $\begin{array}{l}\text { Holiday } \\
\text { home }\end{array}$ & $\begin{array}{l}\text { Vacation or } \\
\text { mountain } \\
\text { lodge }\end{array}$ & Camp & Total \\
\hline Larceny & 10,115 & 863 & 146 & 1,333 & 64 & 248 & 12,769 \\
\hline Burglary & 7,398 & 340 & 62 & 3,304 & 86 & 128 & 11,318 \\
\hline Actual bodily harm & 2,481 & 1 & 17 & 42 & 5 & 6 & 2,551 \\
\hline Counterfeit money & 815 & 101 & 920 & 1 & 4 & 1 & 1,840 \\
\hline Damage to property & 1,336 & 104 & 101 & 229 & 12 & 13 & 1,795 \\
\hline Fraud & 925 & 414 & 67 & 21 & 1 & 9 & 1,437 \\
\hline Threat & 1,068 & 35 & / & 91 & 4 & 8 & 1,206 \\
\hline Misappropriation & 965 & 40 & 52 & 1 & / & 6 & 1,063 \\
\hline Violence & 509 & / & & / & l & / & 509 \\
\hline $\begin{array}{l}\text { Production and trade in illicit } \\
\text { drugs, ... }\end{array}$ & 318 & / & / & 46 & / & 5 & 369 \\
\hline Criminal trespass & l & 1 & l & 118 & 2 & 5 & 125 \\
\hline Business fraud & / & 120 & / & 1 & / & 1 & 120 \\
\hline Falsification of documents & & 54 & 53 & l & / & / & 107 \\
\hline $\begin{array}{l}\text { Violation of employees' } \\
\text { fundamental rights }\end{array}$ & / & 82 & / & / & / & / & 82 \\
\hline Arson & & / & l & 33 & / & / & 33 \\
\hline $\begin{array}{l}\text { Abuse of position or trust in a } \\
\text { business activity }\end{array}$ & & / & 31 & / & / & / & 31 \\
\hline
\end{tabular}


(table 6 continued)

\begin{tabular}{|c|c|c|c|c|c|c|c|}
\hline $\begin{array}{l}\text { The number of crimes in the } \\
\text { period } 2007-2013 \text { by } \\
\text { location }\end{array}$ & $\begin{array}{l}\text { Catering } \\
\text { establishment }\end{array}$ & $\begin{array}{l}\text { Hotel, } \\
\text { motel }\end{array}$ & $\begin{array}{l}\text { Gaming/ } \\
\text { Casino }\end{array}$ & $\begin{array}{l}\text { Holiday } \\
\text { home }\end{array}$ & $\begin{array}{l}\text { Vacation or } \\
\text { mountain } \\
\text { lodge }\end{array}$ & Camp & Total \\
\hline $\begin{array}{l}\text { Sexual assault on a person } \\
\text { under the age of fifteen years }\end{array}$ & / & 1 & 1 & I & 9 & 20 & 29 \\
\hline Family violence & & I & l & 25 & l & l & 25 \\
\hline $\begin{array}{l}\text { Misappropriation and } \\
\text { misapplication of foreign } \\
\text { assets }\end{array}$ & 1 & I & 21 & I & I & 1 & 21 \\
\hline $\begin{array}{l}\text { Enabling the use of illicit } \\
\text { drugs or doping in sport }\end{array}$ & I & 1 & 1 & 1 & 2 & I & 2 \\
\hline
\end{tabular}

(Source: Annual Police Reports 2007-2013; author).

\section{Nationality of Criminal Suspects}

Analysis of criminal suspects shows that, most were Slovenian citizens (94\%) followed by nationals of Italy, Bosnia, Croatia and Serbia and Montenegro in small percentages.

Table 7 Number of crimes by nationality of suspects (individuals) committed in accommodation and hospitality facilities in the period 2007-2013.

\begin{tabular}{llllllllll}
\hline NUMBER OF INDIVIDUALS & \multicolumn{10}{c}{ Year } \\
\hline Nationality & 2007 & 2008 & 2009 & 2010 & 2011 & 2012 & 2013 & Total & $\%$ \\
SLOVENIA & 1,661 & 1,508 & 1,549 & 1,492 & 1,508 & 1,350 & 1,152 & 10,220 & 94 \\
ITALY & 39 & 23 & 36 & 45 & 18 & 18 & 27 & 206 & 1.9 \\
BOSNIA \& HERZOGOVINA & 32 & 29 & 24 & 28 & 24 & 25 & 28 & 190 & 1.8 \\
SERBIA \& MONTENEGRO & 20 & 15 & 24 & 23 & 11 & 23 & 10 & 125 & 1.1 \\
CROATIA & 17 & 17 & 18 & 12 & 11 & 14 & 8 & 97 & 0.9 \\
KOSOVO & 0 & 5 & 5 & 6 & 5 & 7 & 5 & 33 & 0.3 \\
Total & & & & & & & & 10,871 & 100 \\
\hline
\end{tabular}

(Source: Annual Police Reports 2007-2013; author).

The results of the comparison of the number of suspects by nationality for criminal offences committed in the period 2007-2013 show that, suspects in $94 \%$ of the crimes taking place in accommodation and hospitality facilities in Slovenia are Slovenian. The remaining 6\% of offences are shared by Italians $(1.9 \%)$, followed by Bosnians $(1.8 \%)$, then citizens of Serbia and Montenegro (1.1\%), $0.9 \%$ represented by citizens of Croatia and $0.3 \%$ by the citizens of Kosovo. A feature of the offences where Italian nationals are suspects is that, they take place in the western part of the country, which is closer to the border with Italy, and where Italian nationals often come as tourists or guests of hospitality facilities. The reasons that common criminals are nationals of Balkan countries require one to look at the socio-economic connections that Slovenia has with these 
countries, for historical reasons and geographical proximity. Unfortunately, the data collected does not state the purpose of the stay or arrival for foreigners in Slovenia, and therefore we cannot determine whether the suspects were in Slovenia as tourists or for other reasons.

Slovenian citizens are the most frequent victims of crime (Table 8) in accommodation and hospitality facilities, followed by nationals of Italy, Bosnia and Herzegovina, Croatia, Serbia and Montenegro, and Kosovo. It is interesting to compare the number of suspects and victims by nationality because we see that, the order is almost identical. When information about offenders and suspects is compared with the number of foreign tourist arrivals $^{39}$ from these countries, we find mostly Italians, followed by Austrians, Germans, Croatians and nationals of Serbia and Montenegro.

Table 8 Victims of crime in accommodation and hospitality facilities during the period 2007-2013 by nationality.

\begin{tabular}{llllllllll}
\hline NUMBER OF INDIVIDUALS & \multicolumn{1}{c}{ Year } \\
\hline Nationality & 2007 & 2008 & 2009 & 2010 & 2011 & 2012 & 2013 & Total & Total \% \\
SLOVENIA & 3,927 & 3,441 & 3,820 & 3,279 & 3,336 & 3,686 & 3,498 & 24,987 & 96.4 \\
ITALY & 49 & 46 & 59 & 64 & 48 & 62 & 66 & 394 & 1.5 \\
BOSNIA \& HERZOGOVINA & 28 & 24 & 26 & 28 & 25 & 29 & 27 & 187 & 0.8 \\
SERBIA \& MONTENEGRO & 21 & 23 & 31 & 20 & 23 & 34 & 27 & 179 & 0.7 \\
CROATIA & 24 & 11 & 21 & 15 & 28 & 30 & 15 & 144 & 0.5 \\
KOSOVO & 0 & 2 & 8 & 2 & 5 & 8 & 3 & 28 & 0.1 \\
Total & 4,049 & 3,547 & 3,965 & 3,408 & 3,465 & 3,849 & 3,636 & 25,919 & 100 \\
\hline
\end{tabular}

(Source: Annual Police Reports 2007-2013; author).

Tourists who have become victims of crime get a negative image of the destination and its safety, which, on their return home, they may also pass on to friends and acquaintances. Social networking over the Internet makes this negative information much more available, which can be damaging to a small destination such as Slovenia. For this reason, it is necessary that, tourist-victims be offered assistance in solving the problems arising from such criminal offences (stolen passport and money); in this way, tourism workers act as security authorities.

\section{CONCLUSION}

Safety is placed very high in the pyramid of values of the tourists or guest. Therefore, tourist safety perception is very important fact in decision making process of choosing the tourist destination or accommodation.

\footnotetext{
${ }^{39}$ Tourist Arrivals and Overnight Stays by Groups of Tourist Accommodations and Countries, Statistical Regions, (Slovenia: SI-STAT Annually).
} 
Therefore, the research's related to tourism safety and security are very important, especially those who based on relevant police or other security stakeholder data. Tourism security data should be collected and analyse more detail. The data from the police whether the victim is a tourist or a guest, would be the key. It would enable a quick and effective analysis of criminal offences in the field of tourism.

The results of the analysis indicate that, the offences that stand out most are larceny and burglary. These are followed by actual bodily harm, counterfeiting money, damage to property, fraud, threats and misappropriation. Other crimes are poorly represented. Counterfeiting money is particularly common in casinos and other locations where larceny is predominant. Most larceny and burglary occurs in catering facilities, which include restaurants, bars, snack bars and patisseries; as there are more of these in Slovenia, we therefore conclude that, the majority of larceny or burglary offences also take place at these locations. The analyses identify criminal offences that are directly connected to tourism (forgery in casinos). On the other side, there are some criminal offences that are indirectly connected to tourism (prostitution); they are not so evident and remain a dark area, which was also shown by the analysis.

One of the most effective methods for preventing larceny and burglary is the quality of protection offered by a building's security system. Certainly, it is hard for owners to adopt because of the significant cost of a quality security system, especially for owners of holiday homes, bungalows and caravans where the most common crimes committed are larceny and burglary. The costs rise sharply with the size of the buildings (hotels, casinos, spas), which is probably not an effective investment, in spite of the fact that, the value of security cannot be measured. The security issues related to accommodation in Europe is mainly focus on the technical aspect of security. This is important especially for higher category accommodations. Namely, it is evident from the analysis of guests' demands that, with a higher hotel category, the role of the security equipment also increases when deciding on which particular hotel to stay in (Cvikl \& Rumbak, 2009: 12) ${ }^{40}$.

The results of the analysis confirm the fact that, the number of crimes in accommodation and hospitality facilities increases during the summer

\footnotetext{
${ }^{40}$ Cvikl H., \& Rumbak R., (2009). Primerjalnaanalizastandardovkakovosti v izbranihevropskihdržavah (Comparative Analsysis of Quality Standards in Selected European Countries), Management, IZobražEVANJE IN TURIZEM-KREATIVNo v SPREMEMBE: ZBornikreferatov: ProceEdings 10-3 (A. Brezovec, \& J. Mekinc eds., Portorož: ZaložbaTuristica-FTŠ UP 2009).
} 
season in July and August. However, the difference compared to other months is not as high as would be expected given the increased number of tourists and consequently overnight stays in July and August. There are definitely more reasons for this small difference. One of them is certainly an increased police presence during the tourist season. During the tourist season, the Slovenian police increasingly cooperate with the police from neighbouring countries in exchanging operative data as the occurrence of pickpockets, organized groups of burglars or thieves who typically move from one tourist place to another regardless of the state borders. In this way, they can be better prepared for the prevention of occurrences of criminal offences. Every year the Slovenian police carry out extra anti-crime actions, as well. Some actions are preventive in nature whereby the police inform tourists on how to take care of their personal safety and the security of their property. At the same time, an increased police presence at the most vulnerable tourist locations deters potential offenders. It is interesting that, most crimes happen in December, but the current data does not provide a relevant argument or make it possible to identify the cause.

The link between increased visits by tourists and visitors and the larger number of offences recorded at weekends (Saturday and Sunday), may be justifiable, but this is not the only reason for such a trend. At the end of the week, when the numbers of guests grow, hospitality facilities hire contract workers, frequently students, who do not know the guests well enough to be able to identify a suspicious person, nor the security systems or other security measures. It is interesting that, the Counterfeit moneymostly occurs on Monday. We have looking for the reason is in the fact that after weekend, bank notes are checked on Monday when the cash is usually taken to the bank.

Compared to other accommodation and hospitality categories, the category of holiday homes (cottages), bungalows and caravans, is revealed to have the most offences committed. It is just the opposite for campsites and holiday and mountain huts, with the least offences committed and also there are fewer of them. The profile of the guests that visit or stay at hospitality facilities may also be among the reasons for the small number of criminal offences.

As the majority of suspects and victims are Slovenian nationals, it is also expected that, they are the most common suspects and, on the other hand, the most common victims. The analysis of suspects' and victims' nationalities reveals some interesting findings, namely that for both suspects and victims the nationalities are comparable.

Opportunities for the development of a tourist destination, do not only 
result from regional development but must also be based on improving how tourists and visitors are welcomed, while effectively tackling certain forms of antisocial and criminal behaviour. Tourism security issues could be managed by cooperation with different stakeholders from the tourism industry, governments, local authorities and security services. The aim would be to strengthen tourist security and the perceived sense of security. This approach is effective if citizens and tourists also become stakeholders in this process. In this way, they could identify unusual events requiring action or attention from the security forces, and report them to the appropriate authorities. Consequently, it is comprehensive security management, in collaboration with commercial operators who directly offer tourism services such as hotels, travel agencies, restaurants and bars; state institutions such as the police, ministries or directorates of tourism, public institutions working in the field of tourism; local institutions, such as regional and local tourism organizations, municipal police officers, various emergency services (fire brigade, mountain rescue, cave rescue etc.), tourist associations, and not least by tourists. In summarising Vršac ${ }^{41}$ (2012), it can be stated that, only by working together can all these tourism entities effectively control the phenomenon of security in destination management, thus creating new value-based management of business processes, assets, capital, information, communications and human resources.

While the problems relating to petty crime (pick pocketing, thefts from apartments, assaults, vandalism and unlawful conduct) may not be particularly significant, they apply to all tourists, without discrimination. The distinctive feature of these sorts of crime is the impact they can have on victims and their daily lives. While the majority of cases and consequences of these types of crime may not be very serious, they can still have a profound impact on a tourist's perceptions of personal security. When faced with such situations, police and other security services initiate specific security measures in high-risk areas, especially where tourists are frequently targeted. Cooperation between local authorities and tourist organisations would allow informative materials and advice on relevant problems to be prepared and circulated to tourists.

There are certain types of crime, such as larceny and fraud, which affect tourists in particular. In such cases, tourists spend (the remainder) of their stay in the destination feeling insecure and being constantly on edge, which will have a decisive impact on the final judgement of their holiday. A significant case of larceny can have an impact on the tourist's final opinion

\footnotetext{
${ }^{41}$ Vršec M., Vlogakorporativnevarnosti, 1 (1) KORPORATIVNAVARNOST 9-11 (2012).
} 
of their visit and cancel out all the positive aspects of their experience, which may mean they would not want to return, and in some cases, may share negative publicity of the tourist destination.

In light of this problem, security stakeholders should implement different measures aimed at confronting these issues. Tourists should be able to send and receive relevant information in all the main tourist areas of the destination. Tourists need efficient access to information and should also be able to report any specific problems they encounter. This could contribute to the configuration of a structured reception system.

Online applications developed especially for tourist security, for use on tablets and the latest smart phones, is one active solution. Such an application should allow tourists to report problems and engage with local police.

In addition, other forms of criminality, including defacing the environment (vandalism by graffiti, which may even be caused by tourists in Rome) or antisocial behaviour (shouting, offensive behaviour, harassment, etc.), have a tremendous impression on tourist insecurity. These forms of uncivil behaviour, negligence and abandonment of public spaces are interpreted by tourists as signs of weakness in the social order and an absence of institutional control.

Many tourism crimes are not reported to the authorities, because tourists might feel that, they cannot explain the crime well enough to the police, the crime is only noticed much later or they feel that there is no point reporting the crime to the Police (Tarlow, 2006, 94-105 ${ }^{42}$; Weaver, 2006, 293-294 ${ }^{43}$ ). A destination's tourist security programme should include giving tourists an efficient reporting and complaints system, in a variety of ways. This could lead to qualitative and quantitative analyses, using indicators for key tourist destination issues. Systematising the resulting security information from those activities previously mentioned would allow detailed identification of advice to offer tourists, using tailored communication and information activities, and are the strong point of a modern approach to safety and security in tourism.

Undoubtedly, the analysis has shown that, we need a more detailed data collection on criminal offences in the field of tourism. More accurate data would enable more precise analyses which would offer useful findings for the hospitality sector. Different stakeholders (public authorities, local communities, owners and managers of accommodation and catering

\footnotetext{
${ }^{42}$ Tarlow Peter E., Crime and Tourism, Tourism in Turbulent Times-Towards SAFE EXPERIEnCE FOR VISITORS 94-105 (Wilks, Pendergast, \& Leggat eds., United Kingdom: ELSEVIER Ltd. 2006).

${ }^{43}$ Weaver D., Sustainable Tourism: TheOry 293-4 (Oxford: Elsevier Ltd. Publishing 2006).
} 
facilities) should plan measures for the provision of security and for criminal offence prevention, based on the findings. The accommodation and catering facilities owners have to dedicate more attention to the safety of their property and the property of their guests. Better cooperation between different security stakeholders is crucial for the tourism security development. 